\title{
Tillage Versus No-Tillage. Soil Properties and Hydrology in an Organic Persimmon Farm in Eastern Iberian Peninsula
}

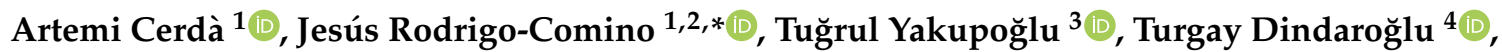 \\ Enric Terol ${ }^{5}$, Gaspar Mora-Navarro ${ }^{5}$, Alireza Arabameri $\left.{ }^{6}{ }^{(}\right)$, Maja Radziemska ${ }^{7}{ }^{\circ}$, \\ Agata Novara ${ }^{8}\left({ }^{\circ}\right.$, Ataollah Kavian ${ }^{9}{ }^{\circledR}$, Magdalena Daria Vaverková ${ }^{10,11}{ }^{(0)}$, \\ Sameh Kotb Abd-Elmabod $\left.{ }^{12}{ }^{(}\right)$, Hafiz Mohkum Hammad ${ }^{13}(-)$ and Ioannis N. Daliakopoulos ${ }^{14}$
}

1 Soil Erosion and Degradation Research Group, Department of Geography, Valencia University, Blasco Ibàñez, 28, 46010 Valencia, Spain; artemio.cerda@uv.es

2 Department of Physical Geography, University of Trier, 54296 Trier, Germany

3 Department of Soil Science \& Plant Nutrition, Faculty of Agriculture, Yozgat Bozok University, 66900 Yozgat, Turkey; tugrul.yakupoglu@bozok.edu.tr

4 Department of Forest Engineering, Faculty of Forestry, Kahramanmaras Sutcu Imam University, 46100 Kahramanmaras, Turkey; turgaydindaroglu@ksu.edu.tr

5 Department of Cartographic Engineering, Geodesy, and Photogrammetry, Universitat Politècnica de València, Camino de Vera, s/n, 46022 Valencia, Spain; eterol@cgf.upv.es (E.T.); joamona@cgf.upv.es (G.M.-N.)

6 Department of Geomorphology, Tarbiat Modares University, Tehran 14117-13116, Iran; alireza.ameri91@yahoo.com

7 Institute of Environmental Engineering, Warsaw University of Life Sciences, 159 Nowoursynowska, 02-776 Warsaw, Poland; maja_radziemska@sggw.pl

8 Dipartimento di Scienze Agrarie, Alimentari e Forestali, University of Palermo, Viale delle Scienze, 90100 Palermo, Italy; agata.novara@unipa.it

9 Department of Watershed Management, Faculty of Natural Resources, Sari Agricultural Sciences and Natural Resources University (SANRU), Sari 4844174111, Iran; a.kavian@sanru.ac.ir

10 Faculty of AgriSciences, Mendel University in Brno, Zemědělská 1, 61300 Brno, Czech Republic; magda.vaverkova@uake.cz

11 Institute of Civil Engineering, Warsaw University of Life Sciences-SGGW, Nowoursynowska 159, 02776 Warsaw, Poland

12 Soil and Water Use Department, Agricultural and Biological Research Division, National Research Centre, Cairo 12622, Egypt; sk.abd-elmabod@nrc.sci.eg

13 Department of Environmental Sciences, COMSATS University Islamabad, Vehari Campus, Vehari 61100, Pakistan; mohkum@ciitvehari.edu.pk

14 School of Agriculture, Hellenic Mediterranean University, 71410 Heraklion, Greece; idaliak@hmu.gr

* Correspondence: rodrigo-comino@uma.es

Received: 6 May 2020; Accepted: 21 May 2020; Published: 28 May 2020

\begin{abstract}
There is an urgent need to implement environmentally friendly agriculture management practices to achieve the Sustainable Goals for Development (SDGs) of the United Nations by 2030. Mediterranean agriculture is characterized by intense and millennia-old tillage management and as a consequence degraded soil. No-Tillage has been widely examined as a solution for soil degradation but No-Tillage relies more on the application of herbicides that reduce plant cover, which in turn enhances soil erosion. However, No-Tillage with weed cover should be researched to promote organic farming and sustainable agriculture. Therefore, we compare Tillage against No-Tillage using weed cover as an alternative strategy to reduce soil losses in persimmon plantations, both of them under organic farming management. To achieve these goals, two plots were established at "La Canyadeta" experimental station on 25-years old Persimmon plantations, which are managed with Tillage and No-Tillage for 3 years. A survey of the soil cover, soil properties, runoff generation and initial soil
\end{abstract}


losses using rainfall simulation experiments at $55 \mathrm{~mm} \mathrm{~h}^{-1}$ in $0.25 \mathrm{~m}^{2}$ plot was carried out. Soils under Tillage are bare $(96.7 \%)$ in comparison to the No-Tillage $(16.17 \%$ bare soil), with similar organic matter (1.71 vs. $1.88 \%$ ) and with lower bulk densities (1.23 vs. $\left.1.37 \mathrm{~g} \mathrm{~cm}^{3}\right)$. Tillage induces faster ponding (60 vs. 92 s), runoff (90 vs. 320 s) and runoff outlet (200 vs. 70 s). The runoff discharge was 5.57 times higher in the Tillage plots, 8.64 for sediment concentration and 48.4 for soil losses. We conclude that No-tillage shifted the fate of the tilled field after 3 years with the use of weeds as a soil cover conservation strategy. This immediate effect of No-Tillage under organic farming conditions is very promising to achieve the SDGs.

Keywords: Tillage; No-Tillage; soil; runoff; erosion; weeds; Iberian Peninsula; persimmon; rainfall simulation

\section{Introduction}

Tillage has been considered as the agricultural management responsible for triggering land degradation in agricultural soils all over the World due to soil erosion acceleration [1,2]. Soil degradation threatens the feat to attain the United Nations Sustainable Goals for Development (SDGs) by 2030. The primary impact of tillage on the soil system is the translocation of soil particles downslope and soil compaction. The assessment of soil redistribution along the hillslopes alarmed the scientists and land managers about the large quantities of soil reallocated [3-6]. However, the immediate effect of tillage erosion as a force that redistributes the soil is only one impact among others. Tillage can also change the physical and chemical conditions of the soil system [7-9]. Moreover, tillage enhances the detachment of soil particles by raindrop impact and runoff generation due to the bare and usually crusted soils after decades of tillage [10-13]. The impact of tillage has been studied from the pedon to landscape scales $[14,15]$ due to his importance to achieve sustainability.

In the Mediterranean basin, the use of tillage is millennia old. The pioneer tillage practices were used in the Mediterranean due to the early development of agriculture in the Fertile Crescent. Tillage was widely used in the Mediterranean due to the climatic conditions that are characterized by recurrent summer droughts that end in a competition for water between the weeds and the crops [16]. The removal of the weeds by tillage was considered one of the most common solution. It is well-established that the three main crops in the classic world in the Mediterranean were cereal (wheat), olives and grapevines. The last two ones have the harvest after three months of summer drought. The climatic conditions and the type of crops determined that intense tillage in summer was the solution to avoid weeds [17]. Tillage was also a strategy to preserve water in the soil during summer as ploughing breaks the capillary continuity thus reducing water evaporation from deep soil layers. However, with the purpose to preserve the water in the soil and avoid weeds, tillage resulted in bare degraded soils with higher erosion rates due to human management. This is demonstrated by Vanwallegem et al. [18] in their historical approach to soil erosion in Mediterranean olive orchards where tillage plays a key role. The soil erosion rates were calculated as 29 till $47 \mathrm{Mg} \mathrm{ha}^{-1} \mathrm{y}^{-1}$, however without affecting the olive production that increased along the eight periods of time researched along a quarter of millennia due probably to the chemical fertilization. Amate et al. [19] also confirmed those findings with information from the social and institutional factors. The historical and pre-historical research also found tillage as an activity contributing to high erosion rates [20]. Tillage and climate change can be considered the main threats that Mediterranean land faced in the last decades and the ones that challenge the future [21,22]. Nowadays, it is widely accepted that tillage is one of the main causes of the highest erosion rates in agricultural lands in the Mediterranean [23].

To reduce the threat of tillage, various strategies have been developed. The alternative management can be diverse such as Novara et al. [24] applied to catch crops in the Sicilian vineyards. For instance, López-Garrido et al., [25] tested reduced tillage, Khan et al., [26] used mulches, Gilley and Risse [27] used 
manure, Bazzoffi et al. [28] urban compost, Faucette et al. [29] mulch blankets, Mtambanengwu et al. [30] weeds, Smets and Poesen [31] geotextiles, Chaowen et al. [32] hedgerows, and Pan and Ma [33] grasses as a cover crop. Furthermore, it is widely accepted that soil erosion is a complex process that is difficult to understand and manage, but also it is accepted that there are already possible solutions [34], and those solutions can be applied in the agriculture [35] and forest lands [36]. For example, No-Tillage is an option to reduce soil erosion rates. No-Tillage has been applied mainly in temperate climates and grain crops under highly mechanized conditions [37-39]. It was also applied in tree crops in the Mediterranean $[40,41]$. Most of the farmers in the Mediterranean used the No-Tillage with massive use of herbicides that avoided any plant cover and resulted in high erosion rates [42]. However, organic farming, which is becoming increasingly popular, dictates that suppression rather than the elimination of weed cover. Weed control is typically accomplished with mechanical means, and this allows a weed cover and mulch that can improve soil properties such as organic matter, soil aggregation and biota [43-45]. However, there is little information about the efficiency of No-Tillage and weed cover in the reduction of the soil and water losses [46,47].

Persimmon plantations are growing in the Eastern Iberian Peninsula due to the proper climatic conditions and powered by the premium prices in the European market. However, recently, this growth increased soil erosion rates such as Bayat et al. [48] and Rodrigo-Comino et al. [49] found using the Improved Stock Unearthing Method, which measures changes in soil topography and at long term periods. The evidence of high and not sustainable soil losses is found in the field where rills, bare soils, crusts and roots exposed are common (Figure 1).
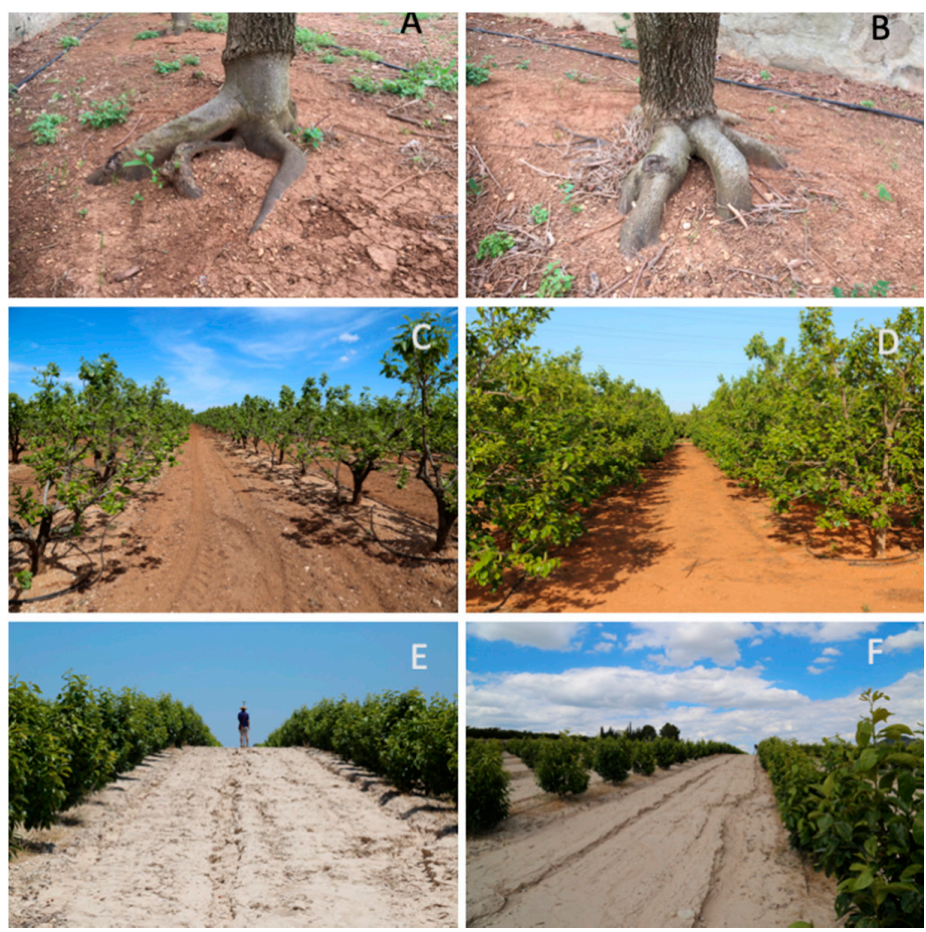

Figure 1. View of persimmon plantations in Eastern Spain. (A,B): root exposure in the "La Canyadeta" experimental station in Canals; (C,D): bare soils in two different parcels in Benimodo and L'Alcúdia; and, (E,F): view of the 4-year-old persimmon plantations in Moixent after a thunderstorm of $30 \mathrm{~mm}$ in $30 \mathrm{~min}$.

In this context, this research aims to determine the impact of No-Tillage on organic farms (with weed cover) in controlling soil and water losses in areas that were previously tilled. This investigation is carried out under an organic farming certified plantation, where farmers strive for optimal sustainable management. Here we applied controlled and precise rainfall simulation experiments at the pedon scale 
to determine how much No-Tillage could change the soil and water losses in persimmon plantations under low frequency-high magnitude rainfall events.

\section{Materials and Methods}

\subsection{Study Area}

Traditionally, persimmon plantations covered the region of L'Alcúdia (Valencia province) and nearby municipalities (Carlet and Benimodo) along the Xúquer River, within an area that coincides with the alluvial plain near the coast. Due demand of the European market and the premium prices offered, persimmon plantations have now expanded to mountainous areas to replace citrus plantations. The study site is located in "La Canyadeta" experimental station, Canals Municipality, La Costera District, in the Eastern Iberian Peninsula. Here, soil parent materials are colluvial sediments from the Cretaceous limestones hillslopes and are classified as Typic Xerothent [50]. The climate is the Mediterranean with 4 months of summer drought from mid-June to mid-September. The nearest meteorological station of Xàtiva Municipality $(6 \mathrm{~km})$ gives a mean annual rainfall of $590 \mathrm{~mm}$ during 41 mean annual days of rain. Autumn is the wettest season with the largest rainfall events reaching as much as $100 \mathrm{~mm}$ day $^{-1}$. The mean annual temperature is $14.2^{\circ} \mathrm{C}$ with August being the warmest month $\left(23^{\circ} \mathrm{C}\right)$ and January the coolest $\left(10^{\circ} \mathrm{C}\right)$. The extreme temperatures registered for the period 1950-2019 were $-9{ }^{\circ} \mathrm{C}$ and $+46^{\circ} \mathrm{C}$.

The study site is planted with a mature (25 years old) plantation of persimmon (Dyospirus lotus var. Rojo brillante). Before June 2011 when the experiment started, the plantation was a conventional agriculture farm utilizing drip-irrigation, fertigation and applying herbicides for weed management, attributes which are representative of the new persimmon plantations in the area (Figure 2A). Trees are planted at $2 \mathrm{~m}$ (between line tree) $\times 5 \mathrm{~m}$ (inter-row). In June 2011, the farm converted to certified organic management. For the requirements of the experiment, the study site was divided into two plots (Figure 2B), one with Tillage (T) and one with No-Tillage (NT), as shown in Figure 2C, and actively managed under the same treatment until July 2014 (Figure 3). In the No-Tillage plot, weeds were suppressed mechanically thus allowing ground cover.

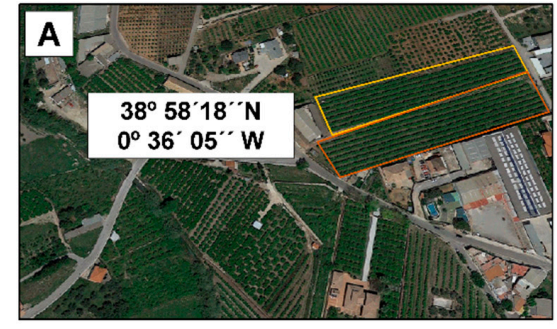

B

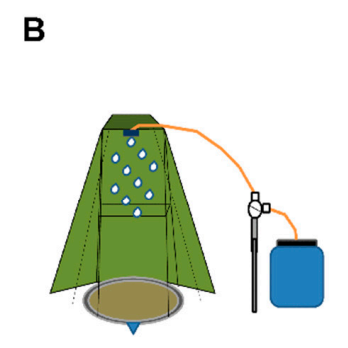

Small portable rainfall simulator $\left(55 \mathrm{~mm} \mathrm{~h}^{-1}\right)$

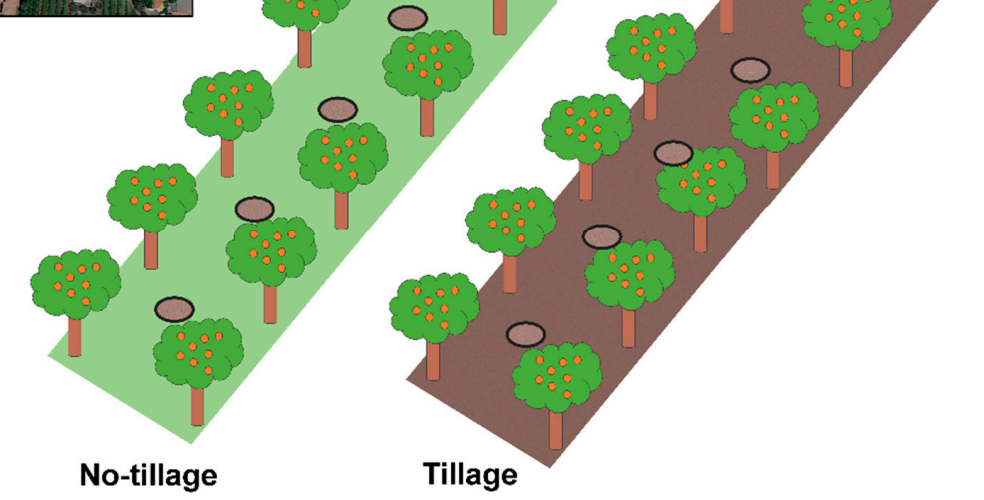

Figure 2. View of the "La Canyadeta" experimental design and plots. (A): location map; (B): rainfall simulator layout; and, (C): experimental design with two rows of persimmon, one under Tillage and one under No-Tillage with weeds. Each one had 25 plots, located in between the persimmon trees, here represented by the circle of the rainfall simulator plot. 

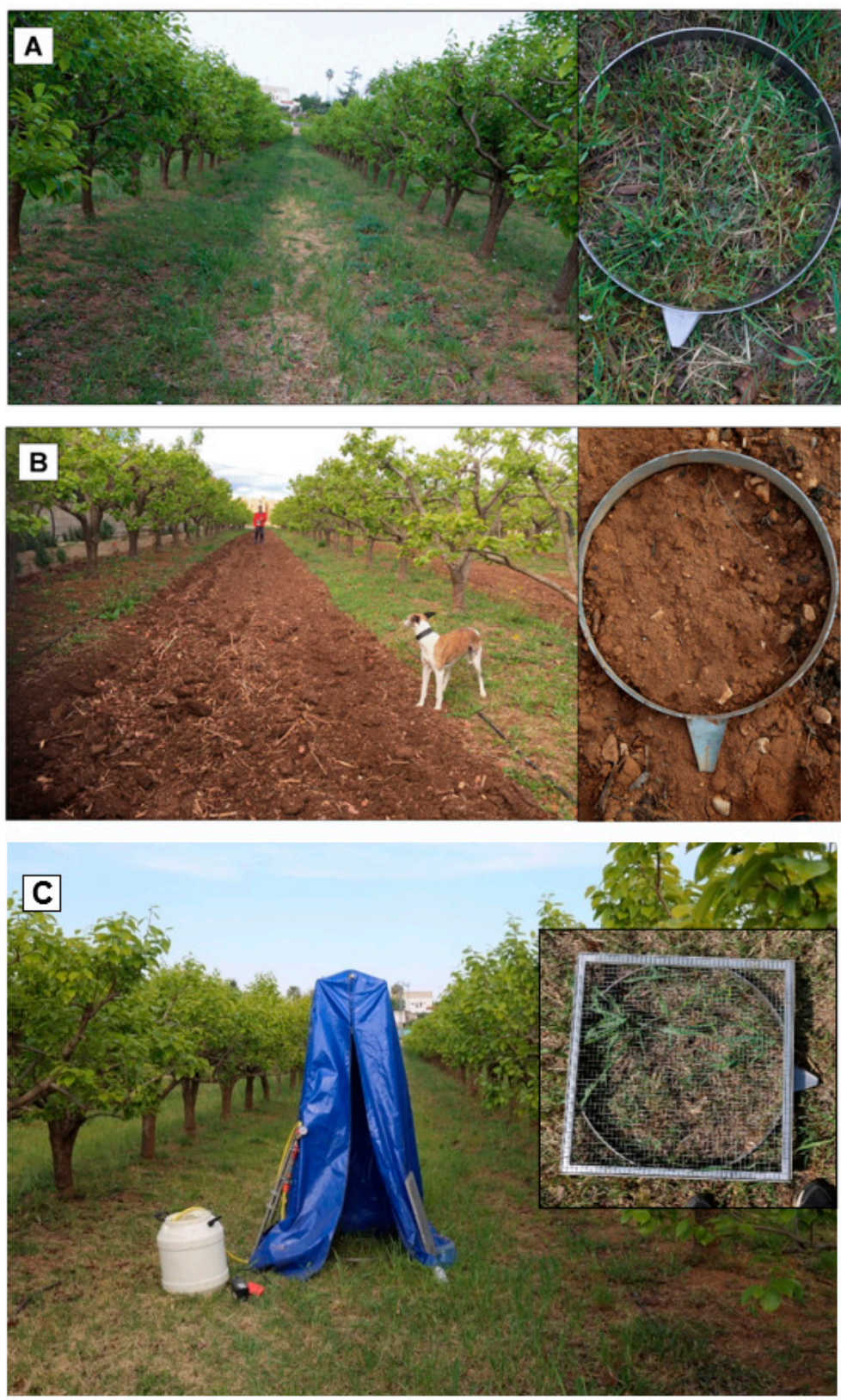

Figure 3. View of the No-Tillage with ground cover (A) and Tillage (B) plots with a detail of the ring subplots for the rainfall simulator. A view of the rainfall simulator and the measurement of the soil surface cover device is shown (C).

\subsection{Sampling Design and Rainfall Simulation Experiments}

The measurements were carried out during July 2014 under very dry soil moisture conditions to avoid changes due to the soil moisture spatial distribution. All the measurements were done in the centre inter-rows (in the cross of the four trees) to avoid the influence of the tree canopy and the drip irrigation (Figure 2C).

Fifty sub-plots ( 25 under Tillage and 25 under No-Tillage) were sampled using a rainfall simulator device [47] under rainfall intensity of $55 \mathrm{~mm} \mathrm{~h}^{-1}$ for $60 \mathrm{~min}$, which amounts to $13.75 \mathrm{~L}$ of rainfall per ring subplot (Figure 3). Rainfall simulator measurements are representative of inter-rill or at the pedon scale and in our investigation we used low frequency-high magnitude rainfall events with 5 year return period at the study area. The rainfall simulator produce drops of $2.53 \mathrm{~mm}$ in average size that fall from 2 m sprayed by a HARDI-1553-10 nozzle (Hardi Sprayer, Nørre Alslev, Denmark) and reach the soil 
surface at $3.4 \mathrm{~m} \mathrm{~s}^{-1}$, with a homogeneous distribution (Christiansen coefficient of 93.2\%) [51,52], and the initial soil erosion processes registered occurred in $0.25 \mathrm{~m}^{2}$. During the rainfall simulation experiments, overland flow from the plot was measured at 1-min intervals. Every fifth 1-min, a runoff sample was collected for laboratory analysis to determine sediment concentration. Sediment concentration $\left(\mathrm{g} \mathrm{L}^{-1}\right)$ in the runoff was calculated after the desiccation of the samples in the laboratory and dividing soil loss (g) by runoff (L). Runoff rates and sediment concentration were used to calculate the sediment yield, total runoff, runoff coefficient, and soil loss rates. The hydrological response of the soils was evaluated considering the time to ponding (Tp), time to runoff (Tr), and time to runoff outlet (Tro) in the field. To better understand runoff generation and transport, Time to runoff - time to ponding ( $\mathrm{Tp}-\mathrm{Tr}$ ) and time to runoff outlet - time to runoff (Tro - Tr) was calculated.

For each subplot, vegetation, litter and rock fragment covers were determined using a frame of $1 \mathrm{~m}$ width with 100 pins measurement in each plot. Soil sampling took place near each subplot before rainfall simulation at two different depths (0-2 and 4-6 cm). Grain size, organic matter and bulk density were determined at each soil sample. The pipette method was applied to determine grain size [53]. Bulk density was calculated using the ring method with a steel ring of $2 \mathrm{~cm}$ depth and $6 \mathrm{~cm}$ wide and another one of $4 \mathrm{~cm}$ depth and $6 \mathrm{~cm}$ wide. Soil organic matter was measured using the Walkley-Black method [54]. Finally, soil moisture was determined by drying soil samples at $105^{\circ} \mathrm{C}$ for $24 \mathrm{~h}$.

\subsection{Statistical Analysis}

To assess the main descriptive statistics (mean, median, maximum and minimum) and perform further statistical analysis, we followed the same procedure applied in [55]. Soil properties were depicted in box plots using SigmaPlot 12.0 (Systat Software Inc., San Jose, CA, USA). Soil loss, runoff and sediment concentration were depicted to represent all the values at each rainfall simulation site obtained during the field campaign using Excel software (Microsoft, Redmond, WA, USA). Then, the hydrological response was summarized in a table. Finally, plot characteristics, hydrological response and soil erosion results were compared, and their statistical differences were evaluated. We perform a one-way ANOVA analysis to check the statistically significant differences among treatments. If the normality test failed (Shapiro-Wilk), a Tukey test was conducted when the homogeneity variance fails (Levene's test). Finally, scatter plots were included using as variables the runoff coefficient and soil losses in order to see the type of trend (linear, logarithmic or exponential). We used the Excel 2016 software.

\section{Results}

\subsection{Plot and Soil Characteristics}

The soil grain size was, on average for the whole dataset, $40.2 \%$ sand, $39.1 \%$ silt and $20.7 \%$ clay (Figure 4), denoting a loam soil. The Tillage plots showed a sand/silt/clay distribution of 40.8/38.9/20.3 and the No-Tillage 39.7/39.3/21. No statistically significant differences were found between Tillage and No-Tillage.

Figure 5 shows ground cover characteristics. After three years, No-Tillage plot is covered with weeds A) meanwhile Tillage plot is mostly bare (B). Measurements show that in the Tillage subplots, $96.8 \%$ (ranging from 93 to $100 \%$ per plot) of the soil is bare, and only some cover takes place. Plant cover is $0.9 \%(0-3 \%)$; litter cover is $0.1(0-1 \%)$ and rock fragment cover is $2.2 \%(0-5 \%)$. On the contrary, on average only $16.8 \%$ (3-27\%) of the No-Tillage plot is bare. The cover is due mainly to the plant cover at $75.8 \%(68-90 \%)$, while $5.5 \%(2-8 \%)$ is litter cover and $1.9 \%(0-8 \%)$ is rock fragment cover.

Figure 6 shows soil properties for 0-2 (Figure 6A,C,E) and 4-6 cm (Figure 6B,D,F) depth. For the surface layer, soil organic matter was $1.85 \%(1.20-2.32 \%)$ at the Tillage and $2.32 \%(1.68-3.01 \%)$ for the No-Tillage. Bulk density at the Tillage plot was $1.22 \mathrm{~g} \mathrm{~cm}^{-3}\left(1.13-2.28 \mathrm{~g} \mathrm{~cm}^{-3}\right)$ and for the No-Tillage $1.36 \mathrm{~g} \mathrm{~cm}^{-3}\left(1.23-1.46 \mathrm{~g} \mathrm{~cm}^{-3}\right)$. Soil moisture content was $6.4 \%(5.3-7.8 \%)$ at the Tillage and $6.0 \%$ (4.3-7.2\%) for the No-Tillage. At 4-6 cm depth soil, organic matter content was $1.56 \%(1.25-1.98 \%)$ at 
the Tillage and $1.43 \%(1.19-1.69 \%)$ for the No-Tillage. The bulk density at the Tillage plot was $1.24 \mathrm{~g}$ $\mathrm{cm}^{-3}\left(1.16-1.69 \mathrm{~g} \mathrm{~cm}^{-3}\right)$ and for the No-Tillage $1.39 \mathrm{~g} \mathrm{~cm}^{-3}\left(1.29-1.50 \mathrm{~g} \mathrm{~cm}^{-3}\right)$. Soil moisture content was $7.8 \%(5.8-9.9 \%)$ at the Tillage and $6.8 \%(6-8.2 \%)$ for the No-Tillage.
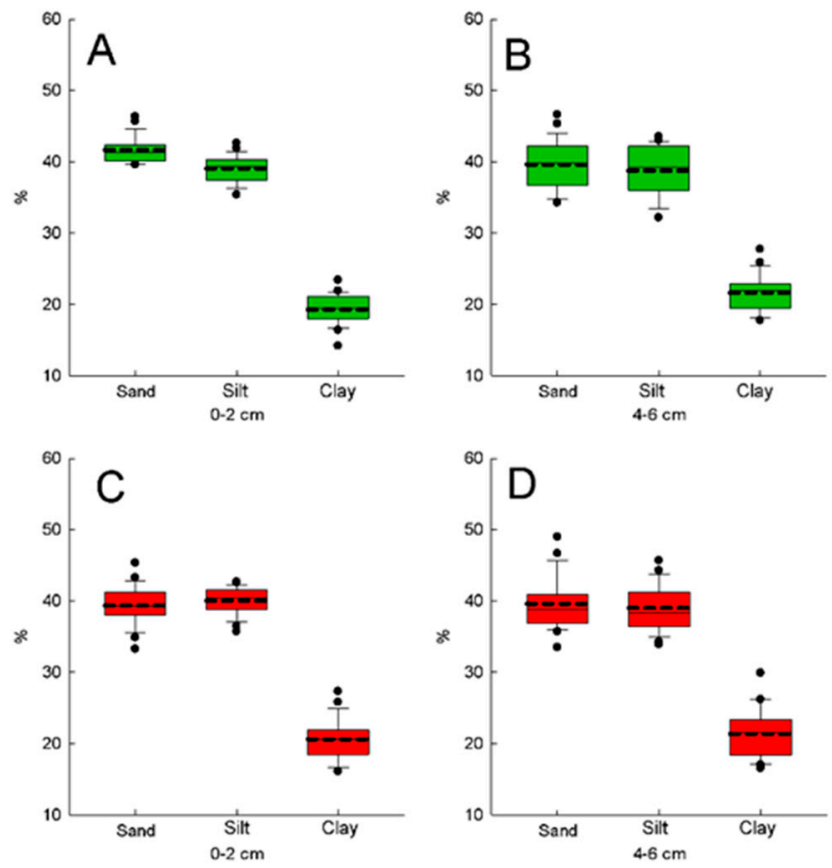

Figure 4. Soil grain size at 0-2 (A,C) and 4-6 (B,D) $\mathrm{cm}$. Sand, silt and clay grain size $(\%)$ for the 25 plots under Tillage (red color) and 25 plots under No-Tillage (green color). Black dotted line: mean values; black thin line: median; points: outliers.
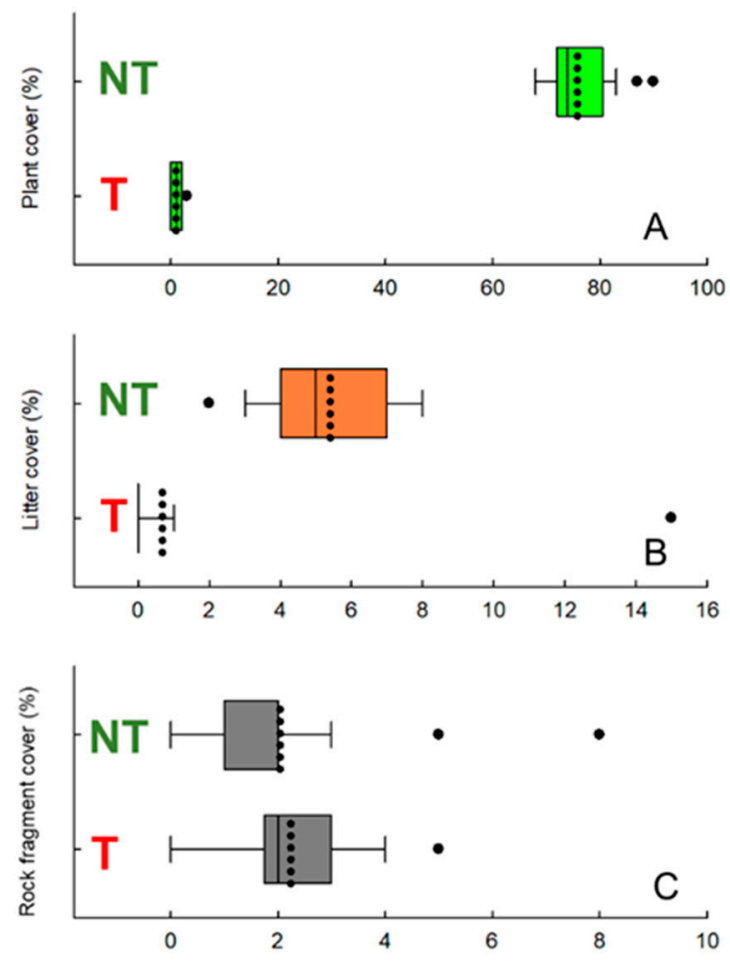

Figure 5. Soil cover. Plant (A), litter (B) and rock fragment cover (C) for the 25 plots under Tillage (T) and 25 plots under No-Tillage (NT). Black dotted line: mean values; black thin line: median; points: outliers. 

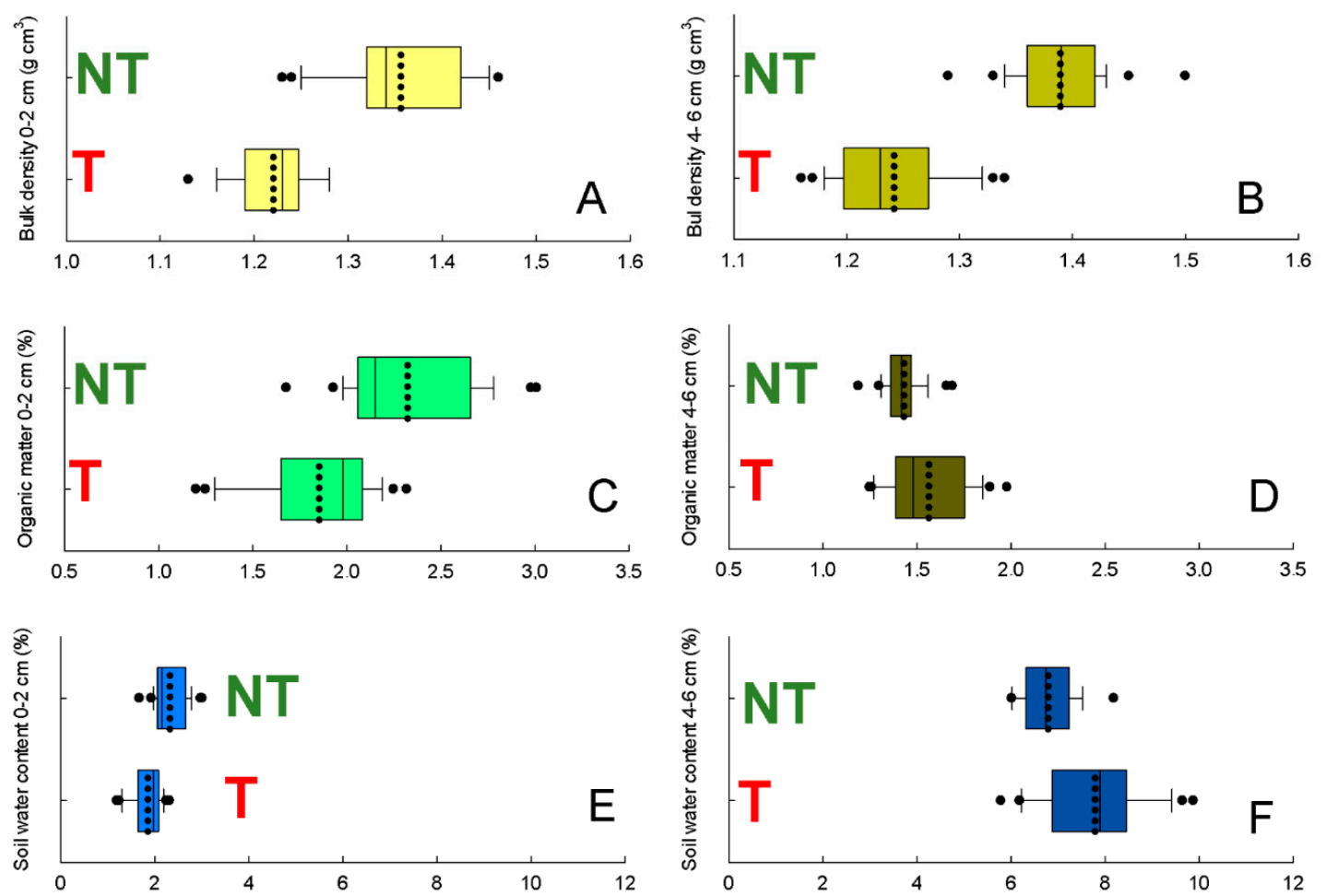

Figure 6. Soil properties at 0-2 (left side) and 4-6 (right side) $\mathrm{cm} . \quad(\mathbf{A}, \mathbf{B})$ : bulk density $\left(\mathrm{g} \mathrm{cm}^{-3}\right)$; $(\mathbf{C}, \mathbf{D})$ : organic matter (\%); (E,F): soil moisture (\%) for the 25 plots under Tillage (T) and 25 plots under No-Tillage (NT). Black dotted line: mean values; black thin line: median; points: outliers.

Finally, in Table 1, we included statistical significance using the ANOVA One-way and Tukey Test (if the Shapiro-Wilk test did not pass). Results show that almost all differences of plot characteristics and soil properties are statistical significant $(P<0.001)$. Rock fragment content and soil texture from 4 to $6 \mathrm{~cm}$ did not show significant differences when tillage is or not applied. Therefore, we can expect that these variables do not influence water and soil losses.

Table 1. Statistical significance $(\mathrm{P})$ among plot characteristics and soil properties differences.

\begin{tabular}{cccc}
\hline Variable & $\mathbf{P}$ & Variable & $\mathbf{P}$ \\
\hline Plant cover & $<0.001$ & Soil water content $(0-2 \mathrm{~cm})$ & $<0.001$ \\
Litter & $<0.001$ & Soil water content $(4-6 \mathrm{~cm})$ & $<0.001$ \\
Rock fragment cover & $0.278^{*}$ & Sand $(0-2 \mathrm{~cm})$ & 0.005 \\
Bulk density $(0-2 \mathrm{~cm})$ & $<0.001$ & Silt $(0-2 \mathrm{~cm})$ & 0.123 \\
Bulk density $(4-6 \mathrm{~cm})$ & $<0.001^{*}$ & Clay $(0-2 \mathrm{~cm})$ & 0.118 \\
Organic matter $(0-2 \mathrm{~cm})$ & $<0.001$ & Sand $(4-6 \mathrm{~cm})$ & 0.812 \\
Organic matter $(4-6 \mathrm{~cm})$ & 0.038 & Silt $(4-6 \mathrm{~cm})$ & 0.810 \\
& & Clay $(4-6 \mathrm{~cm})$ & 0.800 \\
\hline
\end{tabular}

* Passed normality test (Shapiro-Wilks) and ANOVA-One way were conducted.

\subsection{Runoff Initiation}

In Table 2, the hydrological response after performing every rainfall simulation experiments are summarized. The ponding was reached in the Tillage plots after $62 \mathrm{~s}$ in average (range from $53 \mathrm{~s}$ as the minimum and $75 \mathrm{~s}$ as maximum), and runoff $92 \mathrm{~s}$ since the rainfall started (82-98 s). The delay from ponding to runoff was 30 seconds (11-44 s). The runoff outlet was measured after 212 s (159-274 s) and the delay from runoff to runoff outlet was $120 \mathrm{~s}$ (65-180 s).

No-Tillage plots shown a delayed initiation of the ponding (124 s; 112-142) and runoff (229 s; 302-384 s), and then the ponding was transformed into runoff after $214 \mathrm{~s}$, ranging from 119 to $249 \mathrm{~s}$. 
The runoff outlet was measured after $686 \mathrm{~s}(625-785 \mathrm{~s})$ and the delay from runoff to runoff outlet was $348 \mathrm{~s}(277-440 \mathrm{~s})$.

Table 2. Mean, standard deviation (SD), maximum (Max) and minimum (Min) values for the Time to ponding (Tp), Time to runoff (Tr), Tp-Tr, Time to runoff outlet (Tro). T: Tillage; NT: No-Tillage.

\begin{tabular}{ccccccccccc}
\hline & \multicolumn{2}{c}{ Tp } & \multicolumn{2}{c}{ Tr } & \multicolumn{2}{c}{ Tp-Tr } & \multicolumn{2}{c}{ Tro } & \multicolumn{2}{c}{ Tr-Tro } \\
\hline & T & NT & T & NT & T & NT & T & NT & T & NT \\
\hline Mean & 62 & 124 & 92 & 339 & 30 & 214 & 212 & 686 & 120 & 348 \\
SD & 5.2 & 7.8 & 5.8 & 21.8 & 8.6 & 19.6 & 27.7 & 46.0 & 30.3 & 42.8 \\
Max & 75 & 142 & 98 & 384 & 44 & 249 & 274 & 785 & 188 & 444 \\
Min & 53 & 112 & 82 & 302 & 11 & 190 & 159 & 625 & 65 & 277 \\
P & $<0.001$ & $<0.001$ & $<0.001$ & $<0.001$ & $<0.001$ \\
\hline
\end{tabular}

\subsection{Water and Soil Losses}

The discharge was measured at plot outlet and resulting runoff coefficient and erosion metrics are depicted in Figure 7. The analysis demonstrated a statistically significant difference at $P<0.001$ for all variables. Tillage plots show a total runoff of $5.3 \mathrm{~L}(4.3-7.7 \mathrm{~L})$ upon the $13.75 \mathrm{~L}$ of the rainfall. This results in a runoff coefficient of 38.7\% (31.1-56.3\%). The No-Tillage plots showed an average runoff discharge de $0.96 \mathrm{~L}(0.6-1.3 \mathrm{~L})$ with a runoff coefficient of $7 \%(4.3-9.5 \%)$. For both parameters, the differences between Tillage and No-Tillage are statistically significant.

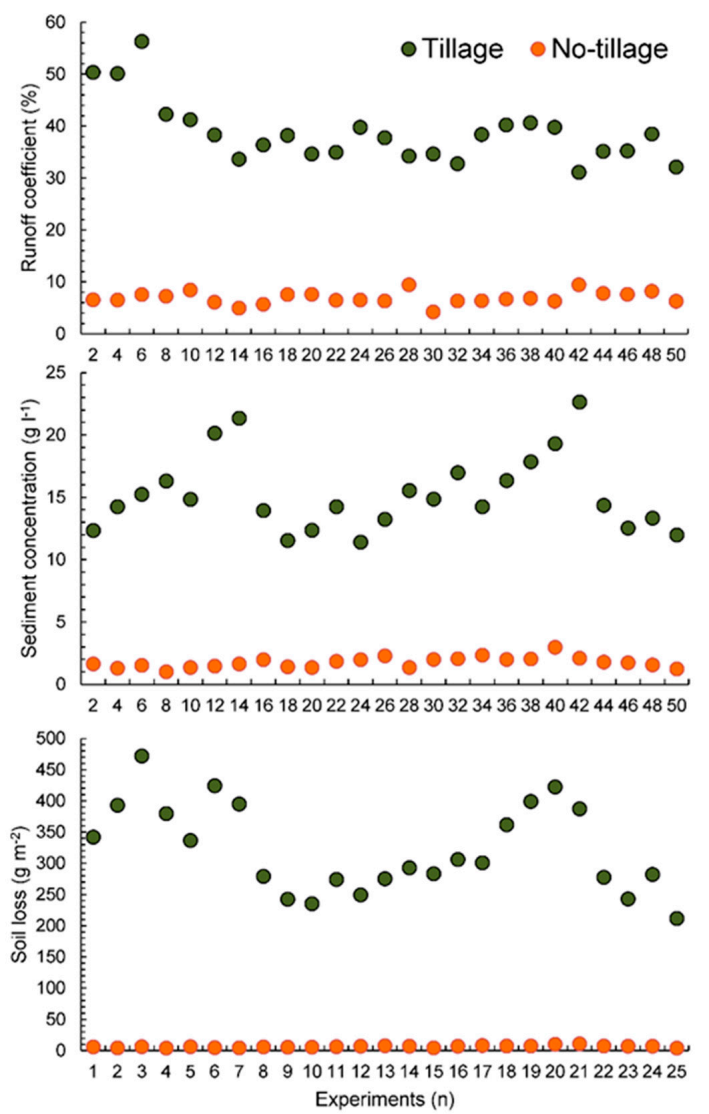

Figure 7. Soil hydrological and erosional response along the two inter-rows studied using simulated rainfall experiments. The distance between the plot was $2 \mathrm{~m}$. A: Runoff coefficient (\%); B: Sediment concentration $\left(\mathrm{g} \mathrm{L}^{-1}\right)$ and, $\mathrm{C}$ : Soil erosion rate $\left(\mathrm{g} \mathrm{m}^{-2}\right)$. 
The average sediment concentration of the runoff was of $15.3 \mathrm{~g} \mathrm{~L}^{-1}\left(11.4-22.7 \mathrm{~g} \mathrm{~L}^{-1}\right)$ for the Tillage plots and $1.8 \mathrm{~g} \mathrm{~L}^{-1}\left(1-3 \mathrm{~g} \mathrm{~L}^{-1}\right)$ for the No-Tillage plots. The total sediment delivered was $322.8 \mathrm{~g} \mathrm{~m}^{-2}$ (221-472.1 $\mathrm{g})$ for the Tillage plots and $6.67 \mathrm{~g} \mathrm{~m}^{-2}\left(4.0-10.9 \mathrm{~g} \mathrm{~m}^{-2}\right)$ for the No-Tillage plots. Upscaling these results, soil erosion rates yield a total of $3.23 \mathrm{Mg} \mathrm{ha}^{1} \mathrm{~h}^{-1}\left(2.12-4.72 \mathrm{Mg} \mathrm{ha}^{1} \mathrm{~h}^{-1}\right)$ for the Tillage plots and $0.07 \mathrm{Mg} \mathrm{ha}^{1} \mathrm{~h}^{-1}\left(0.04-0.11 \mathrm{Mg} \mathrm{ha}^{1} \mathrm{~h}^{-1}\right)$ for the No-Tillage ones.

\section{Discussion}

Our experimental investigations in "La Canyadeta" research station found that Tillage induces higher erosion rates. Our approach at the pedon scale under rainfall simulations confirms the findings of previous publications. Poulenard et al. [56] studied with rainfall simulation experiments in the Ecuadorian Páramo an increase from 80 to $120 \mathrm{~g} \mathrm{~m}^{-2}$ due to the tillage and informed how a porous soil was transformed into a highly erodible soil due to the abuse of ploughing. In the persimmon plantation researched at the "La Cañadeta" experimental station, we measured in three years from $323 \mathrm{~g} \mathrm{~m}^{-2}$ to $6.7 \mathrm{~g} \mathrm{~m}^{-2}$ which, we can consider as a great success. Other authors found tillage as the management with the highest soil losses and the alternative managements with the lowest ones [57]. Those results use to be relevant for groves, where the research need more surveys, for example, in the investigations conducted by Zhang et al., [35] in citrus plantation under heavy rainfall, as they found that in the comparison between Tillage and No-tillage resulted in a reduction in $26 \%$ in the runoff and $92 \%$ in the soil losses. Moreover, in vineyards was found a positive impact of the Tillage. Mirás-Avalos et al. [58] applied measurement on No-Tillage with mulching and weeds and they found that the soil losses were 0.36 and $0.42 \mathrm{Mg} \mathrm{ha}^{-1}$, respectively. But under the Tillage the soil losses were $0.84 \mathrm{Mg} \mathrm{ha}^{-1}$. Tillage also affects runoff discharge. We found a reduction from $39 \%$ runoff in the Tillage plots, to $7 \%$ in the No-Tillage one. The investigations conducted by Jin et al. [59] resulted in a similar reduction under natural rainfall where for six years they measured $11.1 \mathrm{~mm}$ of runoff in average in the plots under Tillage and only $0.36 \mathrm{~mm}$ in the No-Tillage plots.

The findings at "La Cañadeta" shown that the time to runoff was delayed with the plant crop developed after the use of No-Tillage for three years. And this is related to the reduced runoff discharge that reduced from $5.32 \mathrm{~L}$ to $0.96 \mathrm{~L}$ (Figure 8).

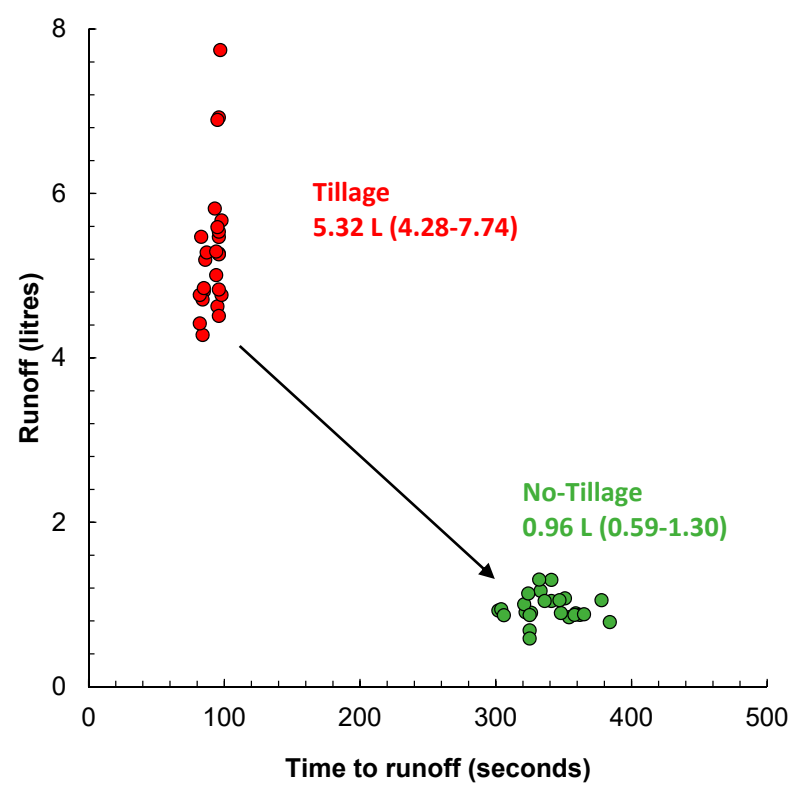

Figure 8. Relation between Time to runoff (s) and Runoff (L) for Tillage and No-Tillage plots (n $25+25$ ) at the experimental station "La Cañadeta".

Many authors consider Tillage as a threat to the sustainability of the agriculture land due to the high erosion rates induced [60,61]. Novara et al. [62] measured $9.5 \mathrm{Mg} \mathrm{ha}^{-1} \mathrm{y}^{-1}$ and considered that 
the Sicilian vineyards are under an environmental problem. Vineyards are especially sensitive such as the recent research of Rodrigo-Comino et al. [63,64] in Germany and Spain. Biddoccu et al. [65] and Capello et al. [66] in North-West Italy or Napoli et al. [67] in the Chianti region in Italy, and Pappalardo et al. [68] in the Prosecco region; David et al. [69] and Morvan et al. [70] in France.

Soil erosion is higher in the tilled soils due to the loss of vegetation cover that contributes to a more efficient raindrop impact such as Fernández Raga et al. [71] or Marzen et al. [72] found in their researches. The contribution of the raindrop impact and the splash detachment is negligible when the soil is covered with plants or mulches [73]. Another key mechanism that determines the higher soil losses is the crust formation during the rainfall periods such as Dalla Rosa et al. [74] demonstrated under tillage condition and simulated rainfall events such as we performed in La Cañadeta experimental station. Crusts reduce soil infiltration capacity, but also, they reduce the surface roughness and increase the soil losses. This was measured by Zhao et al. [75] under simulated rainfall too. But, if Tillage is the problem, our research contributes with a solution to the non-sustainable soil erosion rates: No-Tillage. The vegetation cover is a good strategy and enough efficient to reduce soil erosion rates. Other strategies to control the soil losses are the use of polymers [76], straw mulches [77], geotextiles [78] or grass buffer strips [79,80].

During the last three decades, persimmon plantations grew in the Eastern Iberian Peninsula due to the premium prices in the European market. The expansion of the persimmon plantations occurred mainly on the territories planted with citrus orchards, including the use of tillage, herbicides and highly innovative irrigation and spraying systems. However, this new and highly innovative agriculture did not pay attention to soil erosion control measures. Farmers and policymakers improved the production system with more mechanization and the use of chemicals but there was not a change in the direction (increase production and avoid the ecosystem conservation) to achieve sustainability. Organic farming, on the contrary, is looking for the production of healthy food from and environmental and human point of view. However, organic farming allows tillage as a strategy to control the weeds. This paper showed that in the absence of vegetation (weed) ground cover, Tillage induced 50 times higher erosion rates in organic farming persimmon plantations. Both, runoff and soil loss were reduced due to the No-Tillage strategy (Figure 9).

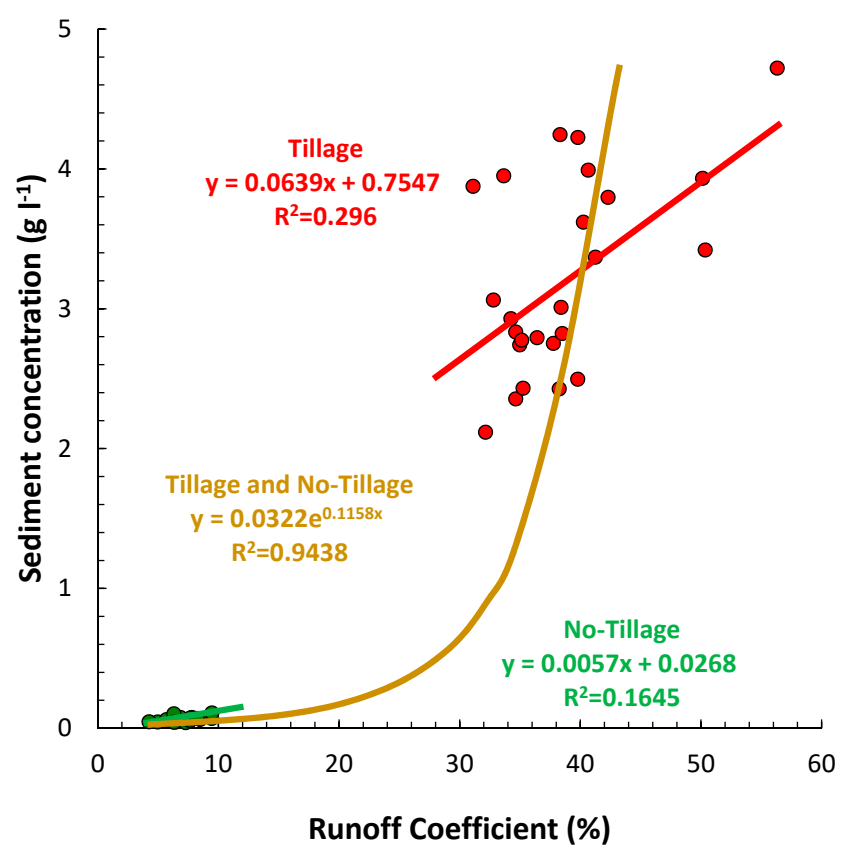

Figure 9. Relation between runoff coefficient (\%) and soil erosion $\left(\mathrm{Mg} \mathrm{ha}^{-1} \mathrm{y}^{-1}\right)$ for Tillage and No-Tillage plots (n $25+25)$ at the experimental station "La Cañadeta". 


\section{Conclusions}

The use of No-Tillage has been found as a potential solution to the high and non-sustainable soil losses found in agriculture land such as the persimmon plantations. The experimental research conducted using rainfall simulation experiments and soil sampling and surface cover measurements demonstrate that No-tillage in 3 years increases the cover from 3 to $83 \%$ vegetation cover, slightly increased the soil organic matter at the soil surface layer (from 1.9 to $2.3 \%$ ), and the soil bulk density ( 1.23 to $1.37 \mathrm{~g} \mathrm{~m}^{-3}$ at $0-6 \mathrm{~cm}$ depth). No-Tillage delayed the ponding, runoff and runoff outlet, and this was definitive to reduce the runoff discharge from 37 to $7 \%$ of the simulated rainfall ( $55 \mathrm{~mm}$ in $1 \mathrm{~h}$ ). The soil erosion rates shifted after three years of No-Tillage from 3.2 to $0.07 \mathrm{Mg} \mathrm{ha}^{-1} \mathrm{~h}^{-1}$. The reduction of the soil erosion rates in two orders of magnitude in 3 years of No-Tillage confirms that No-Tillage is an efficient alternative for the sustainable production of Persimmon. We developed the concept window of improvement to show with graphs and numbers the positive effect of No-Tillage in agriculture land.

Author Contributions: Conceptualization, A.C.; J.R.-C.; T.Y.; T.D.; E.T.; G.M.-N.; A.A.; M.R.; A.N.; A.K.; M.D.V.; S.K.A.-E.; H.M.H.; I.N.D.; methodology, A.C.; J.R.-C.; E.T.; G.M.-N.; A.N.; A.A.; software, A.C.; J.R.-C.; T.Y.; A.K.; M.D.V.; S.K.A.-E validation, A.C.; J.R.-C.; T.D.; E.T.; G.M.-N.; formal analysis, A.C.; J.R.-C.; T.Y.; T.D.; E.T.; G.M.-N.; A.A.; H.M.H.; M.R.; A.N.; A.K.; M.D.V.; S.K.A.-E.; I.N.D.; investigation, A.C.; J.R.-C.; T.Y.; T.D.; E.T.; G.M.-N.; A.A.; H.M.H.; M.R.; A.N.; A.K.; M.D.V.; S.K.A.-E.; I.N.D.; resources, A.C.; J.R.-C.; T.Y.; T.D.; E.T.; G.M.-N.; A.A.; M.R.; A.N.; A.K.; M.D.V.; S.K.A.-E.; I.N.D.; data curation, A.C.; J.R.-C.; T.Y.; T.D.; E.T.; G.M.-N.; A.A.; M.R.; A.N.; A.K.; M.D.V.; S.K.A.-E.; I.N.D.; writing—original draft preparation, A.C.; J.R.-C.; I.N.D.; writing—review and editing, A.C.; J.R.-C.; T.Y.; T.D.; E.T.; G.M.-N.; A.A.; H.M.H.; M.R.; A.N.; A.K..; M.D.V.; S.K.A.-E.; I.N.D.; visualization, A.C.; J.R.-C.; T.Y.; T.D.; E.T.; G.M.-N.; A.A.; H.M.H.; M.R.; A.N.; A.K..; M.D.V.; S.K.A.-E.; I.N.D.; supervision, A.C.; J.R.-C.; project administration, A.C.; funding acquisition, A.C. All authors have read and agreed to the published version of the manuscript.

Funding: This research was funded by the European Union Seventh Framework Programme (FP7/2007-2013) under grant agreement 603498 (RECARE project). Artemi Cerdà thanks the Co-operative Research programme from the OECD (Biological Resource Management for Sustainable Agricultural Systems) for its support with the 2016 CRP fellowship (OCDE TAD/CRP JA00088807).

Acknowledgments: We thank Nathalie Elisseou Léglise for her kind management of our financial support. We wish to thank the Department of Geography secretariat team (Nieves Gómez, Nieves Dominguez and Susana Tomás) for their support along three decades to our research at the Soil Erosion and Degradation Research team (SEDER), with special thanks to the scientific researchers that as visitors from other research teams contributed to the SEDER research. And we also thank the Laboratory for Geomorphology technicians (León Navarro) for the key contribution to our research. The collaboration of the Geography and Environmental Sciences students was fruitful and enjoyable. The music of Hilari Alonso (Vetlatori de Tavernes) was an inspiration during the writing of this paper at the COVID19 time.

Conflicts of Interest: The authors declare no conflict of interest.

\section{References}

1. Li, S.; Lobb, D.; Lindstrom, M.J.; Farenhorst, A. Tillage and water erosion on different landscapes in the northern North American Great Plains evaluated using 137Cs technique and soil erosion models. Catena 2007, 70, 493-505. [CrossRef]

2. Blavet, D.; De Noni, G.; Le Bissonnais, Y.; Leonard, M.; Maillo, L.; Laurent, J.; Asseline, J.; Leprun, J.; Arshad, M.; Roose, E. Effect of land use and management on the early stages of soil water erosion in French Mediterranean vineyards. Soil Tillage Res. 2009, 106, 124-136. [CrossRef]

3. Lindstrom, M.; Nelson, W.; Schumacher, T. Quantifying tillage erosion rates due to moldboard plowing. Soil Tillage Res. 1992, 24, 243-255. [CrossRef]

4. Lobb, D.; Kachanoski, R.G.; Miller, M.H. Tillage translocation and tillage erosion on shoulder slope landscape positions measured using 137Cs as a tracer. Can. J. Soil Sci. 1995, 75, 211-218. [CrossRef]

5. Turkelboom, F.; Poesen, J.; Ohler, I.; Van Keer, K.; Ongprasert, S.; Vlassak, K. Assessment of tillage erosion rates on steep slopes in northern Thailand. Catena 1997, 29, 29-44. [CrossRef]

6. Bogunović, I.; Kisić, I.; Jurisić, A. Soil Compaction under Different Tillage System on Stagnic Luvisols. Agric. Conspec. Sci. 2014, 79, 57-63. 
7. Rasmussen, K. Impact of ploughless soil tillage on yield and soil quality: A Scandinavian review. Soil Tillage Res. 1999, 53, 3-14. [CrossRef]

8. Li, Y.; Lindstrom, M.J. Evaluating soil quality-soil redistribution relationship on terraces and steep hillslope. Soil Sci. Soc. Am. J. 2001, 65, 1500-1508. [CrossRef]

9. Alshammary, A.A.G.; Kouzani, A.Z.; Kaynak, A.; Khoo, S.Y.; Norton, M.; Gates, W.; Al-Maliki, M.; Rodrigo-Comino, J. The performance of the DES sensor for estimating soil bulk density under the effect of different agronomic practices. Geosciences 2020, 10, 117. [CrossRef]

10. Le Bissonnais, Y.; Renaux, B.; Delouche, H. Interactions between soil properties and moisture content in crust formation, runoff and interrill erosion from tilled loess soils. CATENA 1995, 25, 33-46. [CrossRef]

11. Bielders, C.L.; Baveye, P.C.; Wilding, L.P.; Drees, L.; Valentin, C. Tillage-induced spatial distribution of surface crusts on a sandy paleustult from Togo. Soil Sci. Soc. Am. J. 1996, 60, 843-855. [CrossRef]

12. Ndiaye, B.; Esteves, M.; Vandervaere, J.-P.; Lapetite, J.-M.; Vauclin, M. Effect of rainfall and tillage direction on the evolution of surface crusts, soil hydraulic properties and runoff generation for a sandy loam soil. J. Hydrol. 2005, 307, 294-311. [CrossRef]

13. Agata, N.; Artemi, C.; Carmelo, D.; Giuseppe, L.P.; Antonino, S.; Luciano, G. Effectiveness of carbon isotopic signature for estimating soil erosion and deposition rates in Sicilian vineyards. Soil Tillage Res. 2015, 152, 1-7. [CrossRef]

14. Papiernik, S.K.; Lindstrom, M.; Schumacher, T.; Schumacher, J.; Malo, D.; Lobb, D. Characterization of soil profiles in a landscape affected by long-term tillage. Soil Tillage Res. 2007, 93, 335-345. [CrossRef]

15. Quine, T.A.; Zhang, Y. An investigation of spatial variation in soil erosion, soil properties, and crop production within an agricultural field in Devon, United Kingdom. J. Soil Water Conserv. 2002, 57, 55-65.

16. Fussell, G.E. Ploughs and ploughing before 1800. Agric. Hist. 1966, 40, 177-186.

17. Bienes, R.; Marques, M.J.; Ruiz-Colmenero, M. Cultivos herbáceos, viñedos y olivares: El manejo tradicional del suelo y sus consecuencias en la erosión hídrica. Cuadernos de Investigación Geográfica 2012, 38, 49-74. (In Spanish) [CrossRef]

18. Vanwalleghem, T.; Laguna, A.M.; Giráldez, J.; Jimenez-Hornero, F.J. Applying a simple methodology to assess historical soil erosion in olive orchards. Geomorphology 2010, 114, 294-302. [CrossRef]

19. Infante-Amate, J.; De Molina, M.G.; Vanwalleghem, T.; Fernández, D.S.; Gómez, J.A. Erosion in the Mediterranean: The case of olive groves in the south of Spain (1752-2000). Environ. Hist. 2013, 18, 360-382. [CrossRef]

20. Van Andel, T.H.; Zangger, E.; Demitrack, A. Land Use and soil erosion in prehistoric and historical Greece. J. Field Archaeol. 1990, 17, 379-396.

21. MacLeod, D.A.; Vita-Finzi, C. Environment and provenance in the development of recent alluvial deposits in Epirus, NW Greece. Earth Surf. Process. Landf. 1982, 7, 29-43. [CrossRef]

22. Ackermann, O.; Greenbaum, N.; Bruins, H.; Porat, N.; Bar-Matthews, M.; Almogi-Labin, A.; Schilman, B.; Ayalon, A.; Horwitz, L.K.; Weiss, E.; et al. Palaeoenvironment and anthropogenic activity in the southeastern Mediterranean since the mid-Holocene: The case of Tell es-Safi/Gath, Israel. Quat. Int. 2014, 328, 226-243. [CrossRef]

23. Meliho, M.; Nouira, A.; Benmansour, M.; Boulmane, M.; Khattabi, A.; Mhammdi, N.; Benkdad, A. Assessment of soil erosion rates in a Mediterranean cultivated and uncultivated soils using fallout 137Cs. J. Environ. Radioact. 2019, 106021, 208-209. [CrossRef] [PubMed]

24. Novara, A.; Gristina, L.; Saladino, S.; Santoro, A.; Cerda, A. Soil erosion assessment on tillage and alternative soil managements in a Sicilian vineyard. Soil Tillage Res. 2011, 117, 140-147. [CrossRef]

25. López-Garrido, R.; Madejón, E.; León-Camacho, M.; Girón, I.; Moreno, F.; Murillo, J.M. Reduced tillage as an alternative to no-tillage under Mediterranean conditions: A case study. Soil Tillage Res. 2014, 140, 40-47. [CrossRef]

26. Khan, M.N.; Gong, Y.; Hu, T.; Lal, R.; Zheng, J.; Justine, M.F.; Azhar, M.; Che, M.; Zhang, H. Effect of slope, rainfall intensity and mulch on erosion and infiltration under simulated rain on purple soil of south-western Sichuan province, China. Water 2016, 8, 528. [CrossRef]

27. Gilley, J.E.; Risse, L. Runoff and soil loss as affected by the application of manure. Biosyst. Eng. 2000, 43, 1583-1588.

28. Bazzoffi, P. The effect of urban refuse compost and different tractors tyres on soil physical properties, soil erosion and maize yield. Soil Tillage Res. 1998, 48, 275-286. [CrossRef] 
29. Faucette, L.B.; Risse, L.M.; Nearing, M.A.; Gaskin, J.W.; West, L.T. Runoff, erosion, and nutrient losses from compost and mulch blankets under simulated rainfall. J. Soil Water Conserv. 2004, 59, 154-160.

30. Mtambanengwe, F.; Nezomba, H.; Tauro, T.; Chagumaira, C.; Manzeke, M.G.; Mapfumo, P. Mulching and fertilization effects on weed dynamics under conservation agriculture-based maize cropping in Zimbabwe. Environments 2015, 2, 399-414. [CrossRef]

31. Smets, T.; Poesen, J. Impacts of soil tilth on the effectiveness of biological geotextiles in reducing runoff and interrill erosion. Soil Tillage Res. 2009, 103, 356-363. [CrossRef]

32. Lin, C.; Tu, S.; Huang, J.; Chen, Y. The effect of plant hedgerows on the spatial distribution of soil erosion and soil fertility on sloping farmland in the purple-soil area of China. Soil Tillage Res. 2009, 105, 307-312. [CrossRef]

33. Pan, C.; Ma, L. How the spatial distribution of grass contributes to controlling hillslope erosion. Hydrol. Process. 2020, 34, 68-81. [CrossRef]

34. Ricci, G.F.; Jeong, J.; De Girolamo, A.M.; Gentile, F. Effectiveness and feasibility of different management practices to reduce soil erosion in an agricultural watershed. Land Use Policy 2020, 90, 104306. [CrossRef]

35. Zhang, N.; Zhang, Q.; Li, Y.; Zeng, M.; Li, W.; Chang, C.; Xu, Y.; Huang, C. Effect of groundcovers on reducing soil erosion and non-point source pollution in citrus orchards on red soil under frequent heavy rainfall. Sustainability 2020, 12, 1146. [CrossRef]

36. Hamadi, A.; Larid, M.; Gómez, J.A.; Ouabel, H. Potential impacts of agroforestry on controlling soil degradation by water erosion in the agricultural lands of Foothills north-west of Dahra (Mostaganem, Algeria). Proceedings 2020, 30, 50. [CrossRef]

37. Phillips, R.E.; Thomas, G.W.; Blevins, R.L.; Frye, W.W.; Phillips, S.H. No-tillage agriculture. Science 1980, 208, 1108-1113. [CrossRef] [PubMed]

38. Awal, R.; Safeeq, M.; Abbas, F.; Fares, S.; Deb, S.K.; Ahmad, A.; Fares, A. Soil physical properties spatial variability under long-term no-tillage corn. Agronomy 2019, 9, 750. [CrossRef]

39. Izquierdo, J.; Milne, A.E.; Recasens, J.; Royo-Esnal, A.; Torra, J.; Webster, R.; Baraibar, B. Spatial and temporal stability of weed patches in cereal fields under direct drilling and harrow tillage. Agronomy 2020, 10, 452. [CrossRef]

40. Álvaro-Fuentes, J.; Plaza-Bonilla, D.; Arrúe, J.L.; Lampurlanés, J.; Cantero-Martínez, C. Soil organic carbon storage in a no-tillage chronosequence under Mediterranean conditions. Plant Soil 2014, 376, 31-41. [CrossRef]

41. Tosti, G.; Benincasa, P.; Farneselli, M.; Guiducci, M.; Onofri, A.; Tei, F. Processing tomato-durum wheat rotation under integrated, organic and mulch-based no-tillage organic systems: Yield, $\mathrm{N}$ balance and $\mathrm{N}$ loss. Agronomy 2019, 9, 718. [CrossRef]

42. Rodrigo-Comino, J.; Giménez-Morera, A.; Panagos, P.; Pourghasemi, H.R.; Pulido, M.; Cerdà, A. The potential of straw mulch as a nature-based solution for soil erosion in olive plantation treated with glyphosate: A biophysical and socioeconomic assessment. Land Degrad. Dev. 2019, in press. [CrossRef]

43. Anastasi, U.; Corinzia, S.A.; Cosentino, S.L.; Scordia, D. Performances of durum wheat varieties under conventional and no-chemical input management systems in a semiarid Mediterranean environment. Agronomy 2019, 9, 788. [CrossRef]

44. Testani, E.; Ciaccia, C.; Campanelli, G.; Leteo, F.; Salvati, L.; Canali, S. Mulch-based no-tillage effects on weed community and management in an organic vegetable system. Agronomy 2019, 9, 594. [CrossRef]

45. Michalopoulos, G.; Kasapi, K.A.; Koubouris, G.; Psarras, G.; Arampatzis, G.; Hatzigiannakis, E.; Kavvadias, V.; Xiloyannis, C.; Montanaro, G.; Malliaraki, S.; et al. Adaptation of Mediterranean olive groves to climate change through sustainable cultivation practices. Climate 2020, 8, 54. [CrossRef]

46. Gómez, J.A.; Romero, P.; Giráldez, J.V.; Fereres, E. Experimental assessment of runoff and soil erosion in an olive grove on a Vertic soil in southern Spain as affected by soil management. Soil Use Manag. 2004, 20, 426-431. [CrossRef]

47. Cerdà, A.; Rodrigo-Comino, J.; Giménez-Morera, A.; Novara, A.; Pulido, M.; Kapović-Solomun, M.; Keesstra, S.D. Policies can help to apply successful strategies to control soil and water losses. The case of chipped pruned branches (CPB) in Mediterranean citrus plantations. Land Use Policy 2018, 75, 734-745. [CrossRef]

48. Bayat, F.; Monfared, A.B.; Jahansooz, M.R.; Esparza, E.T.; Keshavarzi, A.; Morera, A.G.; Fernández, M.P.; Cerdà, A. Analyzing long-term soil erosion in a ridge-shaped persimmon plantation in eastern Spain by means of ISUM measurements. CATENA 2019, 183, 104176. [CrossRef] 
49. Rodrigo-Comino, J.; Ponsoda-Carreres, M.; Salesa, D.; Terol, E.; Gyasi-Agyei, Y.; Cerdà, A. Soil erosion processes in subtropical plantations (Diospyros kaki) managed under flood irrigation in eastern Spain. Singap. J. Trop. Geogr. 2020, 41, 120-135. [CrossRef]

50. USDA, Soil Survey Staff. Keys to Soil Taxonomy, 12th ed.; United States Department of Agriculture: Washington DC, USA, 2014.

51. Iserloh, T.; Ries, J.B.; Cerdà, A.; Echeverría, M.T.; Fister, W.; Geißler, C.; Kuhn, N.J.; León, F.J.; Peters, P.; Schindewolf, M.; et al. Comparative measurements with seven rainfall simulators on uniform bare fallow land. Z. Geomorphol. 2013, 57, 11-26. [CrossRef]

52. Cerdà, A. Soil erosion after land abandonment in a semiarid environment of southeastern Spain. Arid Soil Res. Rehabil. 1997, 11, 163-176. [CrossRef]

53. Deshpande, V.V.; Telang, M.S. Pipet method of sedimentation analysis. rapid determination of distribution of particle size. Anal. Chem. 1950, 22, 840-841. [CrossRef]

54. Walkley, A.; Black, I.A. An examination of the degtjareff method for determining soil organic matter, and a proposed modification of the chromic acid titration method. Soil Sci. 1934, 37, 29-38. [CrossRef]

55. Cerdà, A.; Ackermann, O.; Terol, E.; Rodrigo-Comino, J. Impact of farmland abandonment on water resources and soil conservation in citrus plantations in eastern Spain. Water 2019, 11, 824.

56. Poulenard, J.; Podwojewski, P.; Janeau, J.-L.; Collinet, J. Runoff and soil erosion under rainfall simulation of Andisols from the Ecuadorian Páramo: Effect of tillage and burning. CATENA 2001, 45, 185-207. [CrossRef]

57. Wang, Y.; Cao, L. The effects of tillage practices on interrill erosion in the Red Soil region of China. Trans. ASABE 2020, 63, 211-219. [CrossRef]

58. Mirás-Avalos, J.M.; Ramírez-Cuesta, J.M.; Fandiño, M.; Cancela, J.J.; Intrigliolo, D.S. Agronomic practices for reducing soil erosion in hillside vineyards under Atlantic climatic conditions (Galicia, Spain). Soil Syst. 2020, 4, 19. [CrossRef]

59. Jin, K.; Cornelis, W.M.; Gabriels, D.; Schiettecatte, W.; De Neve, S.; Lu, J.; Buysse, T.; Wu, H.; Cai, D.; Jin, J.; et al. Soil management effects on runoff and soil loss from field rainfall simulation. CATENA 2008, 75, 191-199. [CrossRef]

60. Guo, M.; Zhang, T.; Li, Z.; Xu, G. Investigation of runoff and sediment yields under different crop and tillage conditions by field artificial rainfall experiments. Water 2019, 11, 1019. [CrossRef]

61. Zhang, J.; Hu, Q.; Wang, S.; Ai, M. Variation trend analysis of runoff and sediment time series based on the $\mathrm{R} / \mathrm{S}$ analysis of simulated loess tilled slopes in the Loess Plateau, China. Sustainability 2018, 10, 32. [CrossRef]

62. Novara, A.; Stallone, G.; Cerdà, A.; Gristina, L. The effect of shallow tillage on soil erosion in a semi-arid vineyard. Agronomy 2019, 9, 257. [CrossRef]

63. Rodrigo Comino, J.; Iserloh, T.; Morvan, X.; Malam Issa, O.; Naisse, C.; Keesstra, S.D.; Cerdà, A.; Prosdocimi, M.; Arnáez, J.; Lasanta, T.; et al. Soil erosion processes in European vineyards: A qualitative comparison of rainfall simulation measurements in Germany, Spain and France. Hydrology 2016, 3, 6. [CrossRef]

64. Rodrigo Comino, J.; Iserloh, T.; Lassu, T.; Cerdà, A.; Keestra, S.D.; Prosdocimi, M.; Brings, C.; Marzen, M.; Ramos, M.C.; Senciales, J.M.; et al. Quantitative comparison of initial soil erosion processes and runoff generation in Spanish and German vineyards. Sci. Total Environ. 2016, 565, 1165-1174. [CrossRef] [PubMed]

65. Biddoccu, M.; Ferraris, S.; Pitacco, A.; Cavallo, E. Temporal variability of soil management effects on soil hydrological properties, runoff and erosion at the field scale in a hillslope vineyard, North-West Italy. Soil Tillage Res. 2017, 165, 46-58. [CrossRef]

66. Capello, G.; Biddoccu, M.; Ferraris, S.; Cavallo, E. Effects of tractor passes on hydrological and soil erosion processes in tilled and grassed vineyards. Water 2019, 11, 2118. [CrossRef]

67. Napoli, M.; Marta, A.D.; Zanchi, C.A.; Orlandini, S. Assessment of soil and nutrient losses by runoff under different soil management practices in an Italian hilly vineyard. Soil Tillage Res. 2017, 168, 71-80. [CrossRef]

68. Pappalardo, S.E.; Gislimberti, L.; Ferrarese, F.; Marchi, M.D.; Mozzi, P. Estimation of potential soil erosion in the Prosecco DOCG area (NE Italy), toward a soil footprint of bottled sparkling wine production in different land-management scenarios. PLoS ONE 2019, 14, e0210922. [CrossRef] [PubMed]

69. David, M.; Follain, S.; Ciampalini, R.; Le Bissonnais, Y.; Couturier, A.; Walter, C. Simulation of medium-term soil redistributions for different land use and landscape design scenarios within a vineyard landscape in Mediterranean France. Geomorphology 2014, 214, 10-21. [CrossRef] 
70. Morvan, X.; Naisse, C.; Malam Issa, O.; Desprats, J.F.; Combaud, A.; Cerdan, O. Effect of ground-cover type on surface runoff and subsequent soil erosion in Champagne vineyards in France. Soil Use Manag. 2014, 30, 372-381. [CrossRef]

71. Fernández-Raga, M.; Campo, J.; Rodrigo-Comino, J.; Keesstra, S.D. Comparative analysis of splash erosion devices for rainfall simulation experiments: A laboratory study. Water 2019, 11, 1228.

72. Marzen, M.; Iserloh, T.; Casper, M.C.; Ries, J.B. Quantification of particle detachment by rain splash and wind-driven rain splash. CATENA 2015, 127, 135-141. [CrossRef]

73. Fernández-Raga, M.; Palencia, C.; Keesstra, S.; Jordán, A.; Fraile, R.; Angulo-Martínez, M.; Cerdà, A. Splash erosion: A review with unanswered questions. Earth-Sci. Rev. 2017, 171, 463-477. [CrossRef]

74. Dalla Rosa, J.; Cooper, M.; Darboux, F.; Medeiros, J.C.; Campanaro, C.; Martins Pinto, L.R. Influence of crust formation on soil porosity under tillage systems and simulated rainfall. Hydrology 2017, 4, 3. [CrossRef]

75. Zhao, L.; Hou, R.; Wu, F.; Keesstra, S. Effect of soil surface roughness on infiltration water, ponding and runoff on tilled soils under rainfall simulation experiments. Soil Tillage Res. 2018, 179, 47-53. [CrossRef]

76. Yakupoglu, T.; Rodrigo-Comino, J.; Cerdà, A. Potential benefits of polymers in soil erosion control for agronomical plans: A laboratory experiment. Agronomy 2019, 9, 276. [CrossRef]

77. Cerdà, A.; Rodrigo-Comino, J.; Giménez-Morera, A.; Keesstra, S.D. An economic, perception and biophysical approach to the use of oat straw as mulch in Mediterranean rainfed agriculture land. Ecol. Eng. 2017, 108, 162-171. [CrossRef]

78. Álvarez-Mozos, J.; Abad, E.; Goñi, M.; Giménez, R.; Campo, M.A.; Díez, J.; Casalí, J.; Arive, M.; Diego, I. Evaluation of erosion control geotextiles on steep slopes. Part 2: Influence on the establishment and growth of vegetation. CATENA 2014, 121, 195-203. [CrossRef]

79. Kavian, A.; Saleh, I.; Habibnejad, M.; Brevik, E.C.; Jafarian, Z.; Rodrigo-Comino, J. Effectiveness of vegetative buffer strips at reducing runoff, soil erosion, and nitrate transport during degraded hillslope restoration in northern Iran. Land Degrad. Dev. 2018, 29, 3194-3203. [CrossRef]

80. Morschel, J.; Fox, D.M.; Bruno, J.-F. Limiting sediment deposition on roadways: Topographic controls on vulnerable roads and cost analysis of planting grass buffer strips. Environ. Sci. Policy 2004, 7, $39-45$. [CrossRef]

(C) 2020 by the authors. Licensee MDPI, Basel, Switzerland. This article is an open access article distributed under the terms and conditions of the Creative Commons Attribution (CC BY) license (http://creativecommons.org/licenses/by/4.0/). 